Article

\title{
Planning Urban Manufacturing, Industrial Building Typologies, and Built Environments: Lessons From Inner London
}

\author{
Jessica Ferm ${ }^{1}$, Dimitrios Panayotopoulos-Tsiros ${ }^{1, *}$, and Sam Griffiths ${ }^{2}$ \\ ${ }^{1}$ Bartlett School of Planning, University College London, UK; E-Mails: j.ferm@ucl.ac.uk (J.F.), \\ d.panayotopoulos@ucl.ac.uk (D.P.-T.) \\ 2 Bartlett School of Architecture, University College London, UK; E-Mail: sam.griffiths@ucl.ac.uk \\ * Corresponding author
}

Submitted: 9 April 2021 | Accepted: 13 July 2021 | Published: 23 September 2021

\begin{abstract}
Despite concerns about the loss of industry, industrial land, and buildings in high-value post-industrial cities, there is concurrently a renewed enthusiasm around the potential of "new" urban manufacturing and its contribution to the socioeconomic diversity of cities. Yet, little is known about how planning policy can best support the retention and growth of urban manufacturing. To advance this agenda, this article proposes that we need a better understanding of industrial building typologies and resultant urban form. Using concepts developed by Julienne Hanson to analyse residential morphologies undergoing transformation under modernism, we apply these concepts to investigate the industrial, mixed-use contexts in two areas of London with concentrations of urban manufacturing-Hackney Mare Street and Old Kent Road. The research presented examines how both areas have evolved historically to produce distinctive urban tissues and a range of industrial building typologies. The article reveals that, despite territorial similarities in the late 19th century, the mixed land uses and smaller plot sizes of Hackney Mare Street have allowed for a more resilient development pattern, whereas the greater separation of land uses, large plot sizes, and inward-facing development in the Old Kent Road has facilitated its reimagination for large-scale regeneration. We conclude that greater attention needs to be paid to the relationship between urban manufacturing and built urban form if policies that aim to protect or support the revival of manufacturing in cities are to avoid negative unintended consequences.
\end{abstract}

\section{Keywords}

built environment; industry; London; manufacturing; morphology; planning

\section{Issue}

This article is part of the issue "Future Commercial and Industrial Areas" edited by Angela Million (TU Berlin, Germany) and Felix Bentlin (TU Berlin, Germany).

(C) 2021 by the authors; licensee Cogitatio (Lisbon, Portugal). This article is licensed under a Creative Commons Attribution 4.0 International License (CC BY).

\section{Introduction}

After decades of deindustrialization and the loss or decentralization of large-scale manufacturing, there has been a revival of interest and enthusiasm for smallscale "new" urban manufacturing in the context of the debate around so-called "post-industrial" cities. This has emerged alongside and parallel to the growth of high-tech "advanced" or "smart" manufacturing facilitated by a wave of new technologies driving what is being referred to as a fourth industrial revolution or industry 4.0 (De Propris \& Bailey, 2020). Although some of the small urban-based manufacturing businesses are also benefitting from new digital technologies, Grodach and Martin (2020) situate them in contrast to advanced manufacturers. They characterise them as "low-tech," "high-touch," and labour-intensive firms that benefit from an urban location that provides proximity to networks of suppliers, services, and local labour (Grodach et al., 2017), as well as to consumers and markets that are important for niche design-driven firms (Ferm \& Jones, 2017). 
Despite the enthusiasm for a revival of urban-based manufacturing, the reality in London-the research focus of this article-is that the potential for growth of this sector is threatened by the limited availability of land and buildings to accommodate it. The loss of industrial land has consistently (since 2001) been more than double the target set in London policy, accelerating to three times the target across London in the period of 2011-2015, and almost eight times the target in the central London sub-region (Greater London Authority, 2016). This accelerated loss has been driven by real estate pressures and substantially higher land values for alternative uses, particularly housing, rather than being a direct consequence of deindustrialization (Ferm \& Jones, 2015). It has been facilitated by a widely held assumption that, by definition, manufacturing no longer has a function or place in the post-industrial inner city on the basis that it is dirty, noisy, and an inefficient use of land. Such assumptions fail to take account of a "more nuanced understanding of manufacturing geographies" and the fact that new urban manufacturing businesses "are more likely to cluster in the few remaining pockets of industrial land in the central city" (Grodach \& Martin, 2020, p. 2). In London, there has been some progressive thinking reflected in the new London Plan (Greater London Authority, 2021b; for further elaboration see Ferm, 2021) which acknowledges the need to increase industrial capacity across the city and promotes greater intensification of industrial uses and some co-location with housing. However, the ambitions of those policies, as first drafted, have been undermined by central government pressure for the London Plan to deliver more housing (see letters from the Secretary of State to the Mayor of London, March and December 2020; Greater London Authority, 2021a). This points to the need for new typologies of mixed-use buildings incorporating industry. However, to date, there has been little research undertaken into the typologies of buildings accommodating manufacturing and the relationship between industrial buildings and the urban fabric that surrounds them. In other words, an understanding of how industrial businesses are embedded in, and relate to, their urban environments. This has resulted in a lack of knowledge regarding the impacts of displacement through redevelopment and the best form of new development to accommodate manufacturing in a mixed-use context.

This article is one output of a wider cross-disciplinary research project bringing together Bartlett colleagues in the School of Planning and Space Syntax Laboratory (School of Architecture) at University College London with a shared interest in the place of manufacturing in the "post-industrial" city. The idea is to combine methods and approaches used by collaborators in other projects, drawing on space syntax concepts and analysis, analysis of planning policy and historic documents, and ethnographic and observational work in two inner London case study areas: Old Kent Road, in the London Borough of Southwark, and Mare Street, in the London
Borough of Hackney, part of what has come to be known as the "Maker Mile" (see Figure 1).

Our article draws on Julienne Hanson's conceptualisation of the shifts in the design of post-war social housing in British cities as involving a paradigmatic transformation of urban design ideas driven by architectural modernism (Hanson, 2000). It applies the same principles to an analysis of industrial typologies within mixed-use urban contexts. The next section reviews the literature on the drivers of the location of urban manufacturing, including policy and external economies of agglomeration, arguing that less attention has been paid to the importance of place, urban form, and the built environment in the location of businesses. In order to examine this dimension in more detail, we use Hanson's (2000) original analysis of the changing relationship between buildings and streets in the context of housing design under modernism and seek to apply this to the industrial context. In the following sections, we apply our analysis to two case studies, focusing first on the evolution of urban morphologies in both contexts and second on the variety and distribution of industrial building typologies. The research reveals that, despite demographic and territorial similarities within the late 19th century, the mixed land uses and smaller plot sizes found in Hackney Mare Street have allowed for a more resilient development pattern, whereas the greater separation of land uses, large plot sizes, and more formal, rule-governed environment in the Old Kent Road have facilitated its reimagination for large-scale regeneration. The article concludes that greater attention needs to be paid to the relationships between urban manufacturing activity and built urban form if policies that aim to protect or support the revival of manufacturing in cities are to avoid negative unintended consequences.

\section{The Geography of Urban Manufacturing and Its Relationship to the Built Environment}

Debates in policy and literature on the location of urban manufacturing in the past 40 years or so have drawn attention to the contrasting perspectives of policy-led versus market-led approaches. In the first part of this section, we discuss the related and interconnected drivers of policy and agglomeration economies. However, there is also a strong tradition of literature (e.g., Davis, 2019; Jacobs, 1969; Soja, 2003) that is concerned with the urban morphology of cities and its relationship to the economy. It claims that there is scope for greater attention to be paid to the relationship between urban manufacturing and the material and spatial form of the built urban environment.

Until very recently, the dominant policy approach to industrial land in global cities, including London, has been that of "managed decline" through a gradual reduction in the supply of industrial land that accommodates such businesses, on the basis that we are at the tail end of a long, drawn-out process of deindustrialisation 
and restructuring of the economy (Ferm, 2020). Until the publication of the new London Plan (Greater London Authority, 2021), the approach in previous iterations of London plans was to actively manage the decline of surplus industrial land, whereby the 32 London boroughs fell into one of three categories: "managed," "limited," or "restricted" release. Inherent in such policy approaches is a characterisation of any remaining urban manufacturing as a "relic," associated with the industrialisation of the late 19th and early 20th centuries. Their continued existence has been supported, according to such accounts, by land use policies or statutory zoning approaches that effectively subsidise urban manufacturers to continue to operate in an otherwise high-value city where other land uses would out-bid manufacturers for space (Hills $\&$ Schleicher, 2010). The new London Plan acknowledges the need to retain industrial capacity across London and has moved towards a policy of intensification on industrial land (Policy E7), introducing a mix of uses including housing, rather than supporting piecemeal loss of strategic sites.

Empirical evidence suggests that exclusionary zoning-which serves to prevent other higher-value land uses from locating in an area zoned for industrial use-has remained popular in US city administrations (Dempwolf, 2010; Leigh \& Hoelzel, 2012), and protectionist policies continue to find favour in the new London Plan, albeit with more flexibility than in the past (Ferm, 2021). Arguments in support of industrial zoning are that it helps to diversify the economy and types of jobs available, that it supports the location of small, new firms in central locations at the point when they rely most on the agglomeration benefits of the inner city (Heikkila \& Hutton, 1986), and that industrial areas provide more flexible space, allowing firms to expand and contract more readily (Chapple, 2014). On their own, industrial preservation policies were found by Davis and Renski (2020) to be effective in stemming urban industrial land losses in New York, but the lack of linkage with economic development objectives meant that there was little impact on promoting new industrial business registrations or new employment. The more mainstream economic argument (summarised in Heikkila \& Hutton, 1986) is that zoning inhibits economic efficiency, and that manipulating business location through policy undermines the external economies and benefits of industrial agglomeration and clustering based on market signals.

Yet the characterisation of manufacturing as a relic in cities that would have disappeared through deindustrialisation had it not been for subsidy through planning policy or zoning ignores much theoretical and empirical evidence, particularly on the location of small manufacturers. Whereas market signals led the large-scale mass manufacturers of the Fordist era to decentralise to the newly urbanised suburbia, "business parks" on peripheral greenfield sites, or much further afield to newly industrialised countries, small-scale manufactur- ers, and those in the start-up or incubation phase are more dependent on other businesses in the supply or co-production chain. They are more dependent on labour than capital and have always benefitted from the agglomeration economies found in cities (Jacobs, 1969; Scott, 1982). As Curran (2007, p. 1429) described in her analysis of the displacement of industrial businesses in Williamsburg, New York:

Small urban manufacturers need urban locations for access to customers, suppliers and labour markets. Those businesses that could, left the city long ago; those that remain are the ones that need to be there and have a business advantage because of their urban location.

Unlike the large manufacturers under Fordism, smallscale manufacturers rely on fluid labour markets available in cities and in the production of products that compete on quality over price, there being a benefit to proximity to consumers and access to global markets (Scott, 2006). In contemporary manufacturing, there is a distinction between advanced manufacturers and what Grodach and Martin (2020) call "low-tech, high-touch" manufacturers, the latter being more dependent on the benefits of proximity that cities provide.

More specifically, beyond the importance of a merely urban location, small manufacturing firms are highly place-dependent and tied to specific localities. This local dependence, argue Cox and Mair (1988), results from relationships, trust, and local knowledge built over time, between customers and suppliers in particular places. Small enterprises tend to be more reliant on a local labour force and skills base workers who might not have the capacity to move should the firm be displaced. Unlike large manufacturers who have the capacity to participate in business coalitions to influence local economic development, small manufacturers lack capacity and are more vulnerable. Curran (2010) supports this argument with empirical evidence in Williamsburg, New York, revealing the importance to local manufacturers of place-specific supporting infrastructure and cultural and social networks. In London's East End, Raco and Tunney (2010) also revealed the importance of local linkages for small industrial firms that were affected by redevelopment associated with the 2012 Olympic Games. Many displaced businesses were unable to replicate customer, buyer, and supplier bases elsewhere, bringing attention to the under-acknowledged "peopled nature of SMEs or the relationships of trust and reciprocity that build up between social actors over time" (Raco \& Tunney, 2010, p. 2082). This brings attention to the importance of the local urban context for small manufacturers. As Vaughan et al. (2013) reveal in their study of London's suburbs, industrial uses are part of the delicate ecology and balance of uses in town centres, which is central to understanding why they have remained so adaptable over decades. 
Despite this growing knowledge about the importance of locale for small urban manufacturers, and placespecific social and economic ties, there is little understanding of how the urban fabric can be shaped to accommodate such an ecology. As Soja (2003, p. 274) argues, although the literature on agglomeration economies draws our attention to the "savings in time and energy that derive from clustering things together rather than spreading them out," there is little theoretical or empirical understanding of how this translates into creativity and innovation, and the relationship to wider spatial, social, and historical processes underpinning urban life. Furthermore, the materiality of the city is often overlooked: As Griffiths (2017, p. 127) identifies, although "the urban dimension is acknowledged as critical to the agglomerative process... the natural focus of economists on the instrumental requirements of industry can serve to prioritize the economic 'city of production' at the expense of the quotidian, lived 'city-as-place.' " This article brings the "city-as-place" into central focus through an examination of the evolution of the urban tissue that accommodates industrial typologies and manufacturing activity.

To date, studies of the morphologies of urban environments that accommodate manufacturing are scarce, but there is increasing interest (for an urban design perspective on urban manufacturing in the US context see Lane \& Rappaport, 2020). Wood and Dovey (2015) investigated this issue in relation to creative industries in Australian cities more broadly and found that a mixed morphology linked to a multiplicity of functions was an important factor in creating the "buzz" or "atmosphere" of a creative cluster. Froy and Davis (2017) analysed the relationship between urban form and the location of manufacturing in London's railway arches. They found the arches accommodated a disproportionate amount of manufacturing, which was due to their highly adaptable, flexible, and modular nature suitable for hybrid uses and expanding enterprises, as well as their affordability. Their study points to the potential for an emergent new spatial form: "industrial streets" as opposed to the industrial estates we have seen as the dominant urban form under modernism. The wider impact of a transition from a street-grid urban form that was dominant in the late 19th century to an estate-based one that emerged in the middle of the 20th century has been investigated in the study of housing morphologies by Hanson (2000). Drawing on the space syntax tradition of urban research and analysis, Hanson found that the creation of estate-based social housing morphologies organized around open space rather than streets, inverted the traditional relationship between the building and street. The result was an increased separation of the interior space of estate developments from the life of the urban realm. In social terms, this led to increased segregation of residents of housing estates from the life of the city and reinforced a sense of isolation due to a lack of natural urban encounters, since these estates were gen- erally not entered by people other than those who lived in them. There are parallels here to urban manufacturing, which was also impacted by the transition from a streetbased urban form to an estate-based one, with the result that urban manufacturing's residual presence in industrial estates led both to a sense of its alienness in the city and invisibility in policy terms. This study therefore seeks to apply some of Hanson's thinking to industrial morphologies and the relationship between industrial building typologies, their urban form, and the social and economic life that emerges as a result. We do this through a case study-based investigation of two inner London mixed-use urban areas with concentrations of manufacturing activity, but with very different urban morphological characters that have contributed to their distinctive treatment in policy terms. In the section that follows, we provide a rationale for our case study selection, an overview of the two case studies, and a description of the research methodology adopted.

\section{Case Study Overview and Methodology}

Our case study areas were selected through a two-stage process. In the first stage, a London-wide mapping of manufacturing businesses was conducted (see Figure 1) using business count data from the Directory of London Businesses (London Data Store, 2019), mapped by statistical areas at the medium super output area (MSOA) level. This was overlayed on a space syntax analysis of routes with the highest intensity of use, represented on the map as high "choice" values and thicker lines (for further explanation and discussion see Palominos Ortega et al., 2020). The mapping exercise revealed areas with concentrations of manufacturing businesses.

For the purpose of this article, we were interested in further exploring the morphological characteristics of urban mixed-use areas with concentrations of manufacturing, along well-connected routes, rather than in large tracts of more isolated mono-functional industrial land, as can be seen for example along the River Thames in east London. Therefore, in the second stage of the selection process, we identified areas that met these criteria. Next, we were interested in selecting two case studies that had different historical trajectories of development, policy contexts, and contrasting built environments. The two case studies chosen-Hackney Mare Street and Old Kent Road-are both located in inner London, along A-roads leading out of central London north and south of the River Thames, respectively. They are both outside the original Victorian industrial ring mapped in detail by Peter Hall's (1962) account of the industries of London since 1861, but have had concentrations of manufacturing since at least the 1800s, following the construction of the Regents Canal and Surrey Canal respectively, and later the railway (British History Online, n.d.; Southwark Council, 2021). Yet, the two areas have developed over time in different ways and have experienced different development pressures and policy responses, as will be explained. 


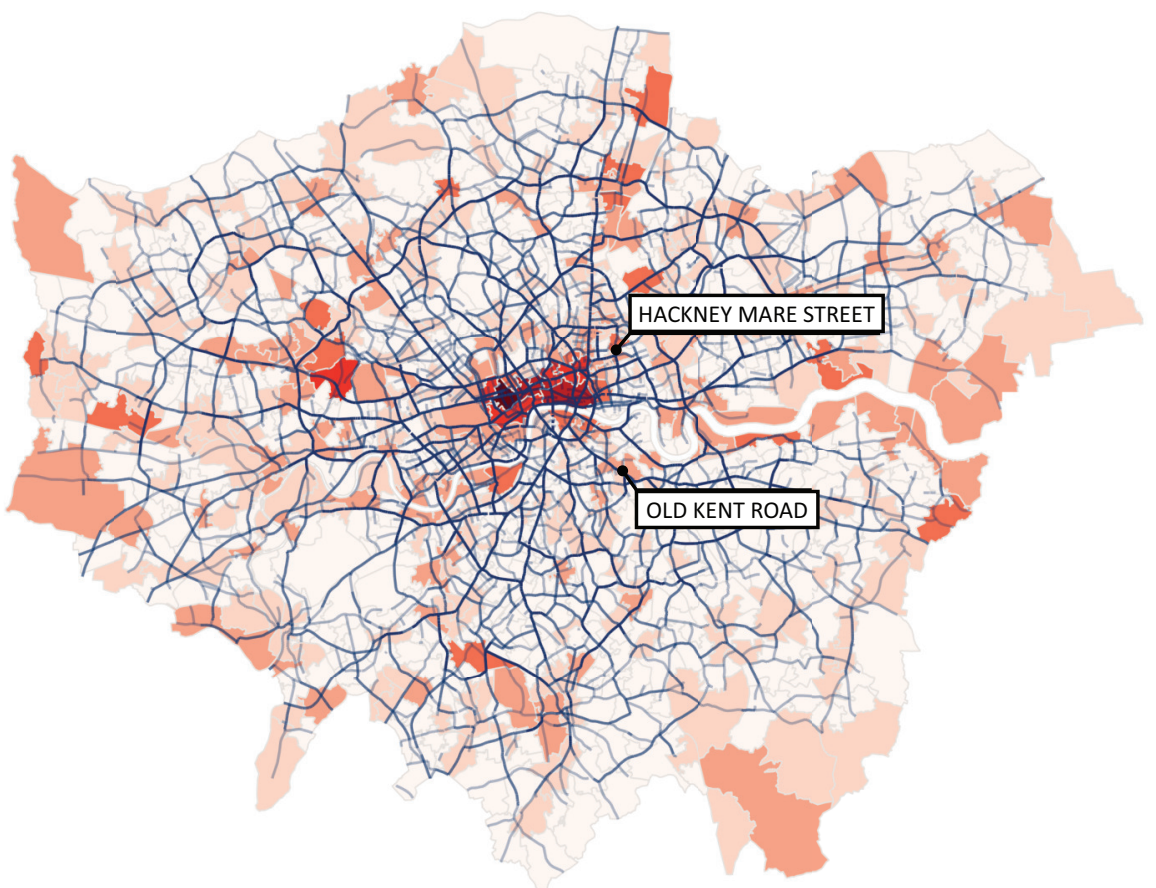

Manufacturing

Business Count

by MSOA

$0.0-10.0$

$10.0-20.0$

$20.0-45.0$

$45.0-90.0$

90.0-160.0

$160.0-260.0$

260.0-365.0

Centrality

(Choice 10km)

Highest 20\% values

- 5.92-6.34

$-6.34-6.81$

- 6.81-7.66

Figure 1. Concentrations of manufacturing businesses in London. The map shows the location of the Hackney Mare Street and the Old Kent Road case studies in London used in this article. Sources: Image elaborated by Nicolas Palominos Ortega using business count data from the Directory of London Businesses (London Data Store, 2019), measured by MSOAs; centrality data retrieved from Space Syntax (2020).

Hackney Mare Street is now part of what has been branded the "Maker Mile" and was featured in the European project "Cities of Making" (Domenech et al., 2020) as a hotspot for new urban manufacturers and creative industries. Hackney has been subject to waves of gentrification, with artist "pioneers" later displaced by middle class gentrifiers and with the "frontline" of gentrification extending geographically north-eastwards over the last few decades (Duman, 2012; Hamnett \& Williams, 1980). This has resulted in both industrial gentrification and industrial displacement by residential redevelopment, with its manufacturing and artistic heritage used in developers' branding strategies (Ferm, 2016). In contrast, the Old Kent Road has long been dismissed as "nothing" - an undesirable thoroughfare and collection of traditional manufacturing, retail depots, and a very run-down high street (Cargill Thompson, 2018). This, along with its designation as strategic industrial land, meant that, until recently, the Old Kent Road was seen by artists, industrial occupiers, and lower-value service businesses as one of the few districts of inner London that had escaped the pressures of gentrification (Cargill Thompson, 2018) and, as such, was relatively protected from displacement by higher value uses. However, the Old Kent Road's identification as an "opportunity area" in the 2016 London Plan and an area of growth in Southwark's local plan, prompted by the planned extension of the Bakerloo Line, has made the area ripe for large-scale redevelopment and has already prompted the piecemeal submission of planning appli- cations for the residential redevelopment of sites (see https://www.vitalokr.com/threat) long before the arrival of the extended Bakerloo Line (now under threat due to lack of government funding).

This article approaches the different development trajectories of these two manufacturing clusters from an urban-morphological perspective in order to better understand how the range and type of manufacturing building typologies identified are embedded in London's historical built environment. In order to meet these objectives, we used the following methods:

Stage 1: Analysis of historical maps, review of historical sources, and policy documents;

Stage 2: Mapping of manufacturing businesses, drawing on the Directory of London Businesses (London Data Store, 2019);

Stage 3: Site visits and observation, using the STRAVA tracking app which allowed the researchers to geolocate any photographs taken. The purpose of the site visits was to (a) verify the data collected in the desktop mapping exercise; (b) identify and map industrial building typologies and identify the activities/uses therein, using observational methods and taking into consideration criteria such as construction type, building and plot size, mixed versus single use, number of storeys, single vs multiple occupancy, and site boundaries; and (c) observe the relationship between 
these typologies and their built environment contexts, exploring accessibility, constitutedness (i.e., streetbuilding interface), urban embeddedness, flexibility of use, and potential for natural urban encounter (see Hanson, 2000);

Stage 4: Semi-structured interviews with business owners or representatives that were selected either during the analysis of the primary data or during the first set of observation-focused visits. Attempts were made to interview businesses in each building typology. The aim of these interviews was to gain insight into the various links between businesses and the built environment related to the location rationale, accessibility, use of space, daily life of employees, and embeddedness. Interviews were transcribed and recorded observations fed into NVivo software for thematic analysis. This analysis used abductive coding whereby codes and themes either emerged from the research itself or were predefined based on theory and the analysis of primary data. The aim of the thematic analysis was to search recurrent underlying themes related to the research framework. As such they covered-in alphabetical orderaccessibility, activity, constitutedness, degree of activity, embeddedness, flexibility, formality/informality, morphology, noise, other, parking, possibility for encounter, safety, and vibrancy. Once the interviews and observations were categorised, they were then used to complete a "typology table" constructed at the beginning of the research to qualify the relationship between each type and its immediate urban environment. This was then simplified and produced in Table 1.

\section{The Urban Morphology of Manufacturing in Hackney Mare Street and Old Kent Road}

The first stage of the research involved an historical overview of Hackney Mare Street and Old Kent Road from the late 19th century onward to detect trends and patterns in the location and clustering of industrial activities. This formed the basis for the empirical research into the spatial morphologies of urban manufacturing, including the configuration of buildings, plots, and streets, and their embedding within the local urban environment. Through our investigation of these two cases, we explore how the aggregation of these features results in tighter or looser urban tissues depending on the relationship between buildings, plots, and streets (see Kropf, 2017). We examine the implications this has for understanding and managing industrial building typologies as part of the evolution of the city fabric. We then use the local empirical findings to discuss the wider relations between manufacturing and the city and reflect on the association with modernism and influence of post-war planning.

The Hackney Mare Street area was, in 1880 (Figure 2), already a densely and heavily urbanised landscape.
By 1951, it had showed little fundamental change in its urban tissue except for the extension of the railway to the north, which incidentally required demolition of part of the urban fabric. Between 1880 and 1951, the incongruent in-between spaces that appeared in the middle of the new railway and the pre-existing urban tissue were gradually filled with larger buildings that started accommodating non-residential uses. Indeed, by 1951 manufacturers of clothing, furniture, chemicals, glass, etc., appear in proximity to the railway (see Figure 2). Notably, these changes coincide with a heavy period of industrialisation during the inter-war period and, as the following sections will explore, their legacy persists to this day.

The Old Kent Road was, until the late 19th century, composed of a mix of farmland, a dense network of residential streets, an extensive rail network, and a cluster of productive activities-manufacturing and various workspaces (e.g., glass works, fur workshops, breweries)-along the Grand Surrey Canal. As Figure 3 shows, the Canal's arrival in the early 1800 s prompted the first wave of industrialisation in the area and acted as a major axis along which further workshops and manufacturing businesses gradually appeared alongside the iconic South Metropolitan Gasworks. These remained, despite the Canal being later covered over (Southwark Council, 2021). By 1952, the entire area was urbanised, and the previous farmland had given way to a dense urban fabric comprising predominantly single row houses along residential streets. Despite the network of railways, the Grand Surrey Canal-by that time covered-remained an organising axis for industry, and its legacy can still be seen in our analysis of the area's contemporary morphology (Figure 4). The Second World War had a devastating impact on the area; the concentration of industry being a target for the bombing raids. The reconstruction of housing and industry that followed resulted in a greater separation of land uses and larger plot sizes. Importantly, Figure 3 also reveals the location of the Bricklayer's Arms station and depot, which was later demolished and developed as a modern industrial estate, warehousing, and distribution area.

With the exception of parks and green communal areas, the urban tissue of both Hackney Mare Street and the Old Kent Road are, today, totally urbanised (Figure 4). However, important distinctions exist in their respective spatial morphologies.

Hackney Mare Street is, today, composed of a mix of densely packed small-scale buildings-predominantly terraced houses-and larger units along major infrastructure axes (see Figure 4). At first glance, the latter seems to fragment the otherwise homogenous residential urban landscape. However, the figure-ground map (Figure 4) and first-person observation (see photographs in Figure 5) indicate that despite this contrast, Hackney Mare Street's urban tissue remains tightly knit and has, to this day, resisted large-scale redevelopment. This could be attributed to the flexibility of the smaller size individual units found around Mare Street-also 

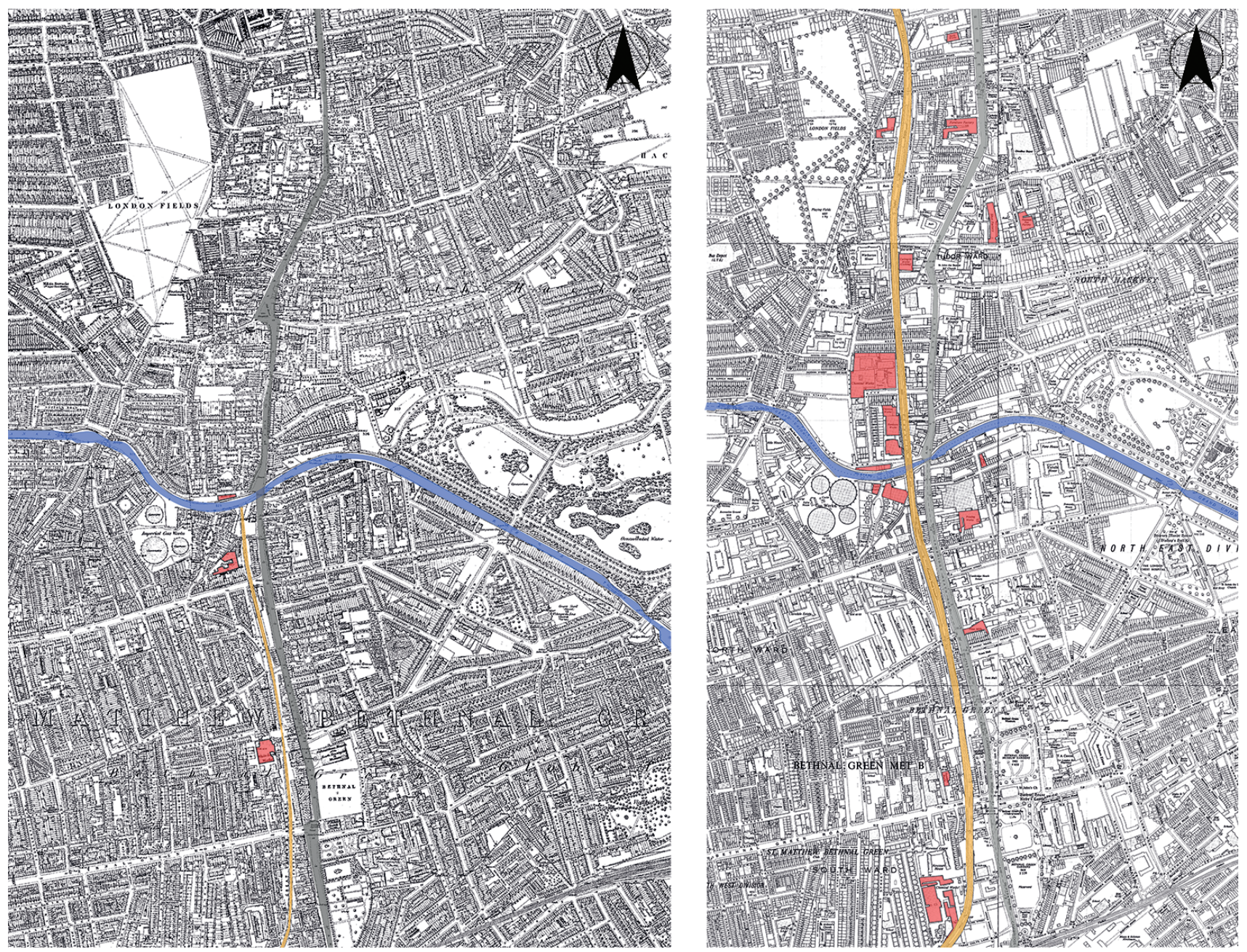

Figure 2. Historical maps of Hackney Mare Street: 1880 (left) and 1951 (right). Highlighted in blue is the Regent's Canal; in orange, the railway; in grey, Mare Street; and in red, manufactories, industrial buildings, and workshops. Source: Ordnance Survey (2019). Created 12 July 2019.

evidenced by its ability to accommodate an entirely new railway line in the early 20th century-allowing the area to evolve incrementally.

In contrast, the Old Kent Road tells a very different story. In the years following 1952, the area saw three extensive transformations: (a) the closure of the Bricklayers Arms Station and Goods Depot, and replacement with a modern industrial estate; (b) the carving of Burgess Park over a pre-existing dense residential and industrial neighbourhood; and (c) the covering of the Grand Surrey Canal (Figure 4). These key events in the transformation of the Old Kent Road area substantially modified the structure of the area's urban fabric. Through these large-scale urban transformations, the historically dense spatial morphology of the Old Kent Road area with outward-facing residences and buildings evolved and is now characterised by a combination of large open spaces and impermeable inward-facing building types on plots with solid perimeters (fencing, blank walls) preventing easy through movement, resulting in an impermeable urban environment (Figure 6).

\section{Building Typologies of Urban Manufacturing}

Despite the contrasting spatial morphologies of both case studies, the range of industrial building typologies found in both areas are broadly similar. What differs-as will be shown later in this section-is the relative dominance of larger format typologies in the Old Kent Road. In the first part of this section, we document our empirical analysis of the range of industrial building typologies found in both areas and their relationships with their direct urban environments. Eight types of buildings were consistently found across both cases (outlined in Table 1 and shown in Figure 7): small-scale industrial buildings, railway arches, industrial estates, large single-occupancy industrial buildings, multi-storey multi-occupancy buildings, containers in container developments, dedicated fenced buildings, and mixed-use developments. Based on the findings from site visits, observations, and interviews, Table 1 unpacks the most common activities found in each type, their respective architectural and morphological characteristics and related degree of flexibility to accommodate productive activities, and finally, 

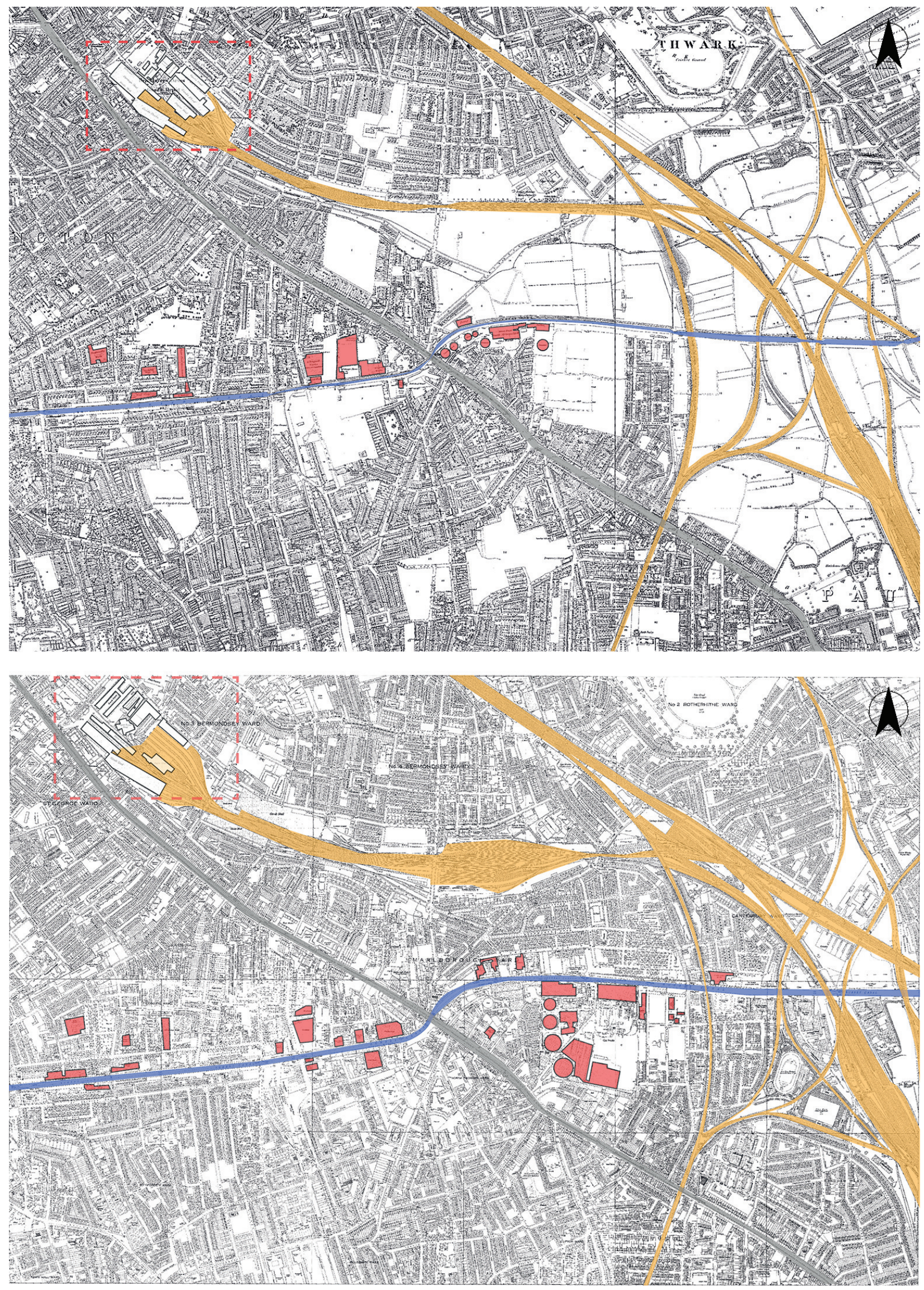

Figure 3. Historical maps of Old Kent Road: 1896 (top) and 1952 (bottom). Highlighted in blue is the Grand Surrey Canal; in orange, the railway; in grey, Old Kent Road; in red, manufactories, industrial buildings, and workshops; and, in white, the Bricklayers Arms Station and Depot. Source: Ordnance Survey (2019). Created 12 July 2019. 

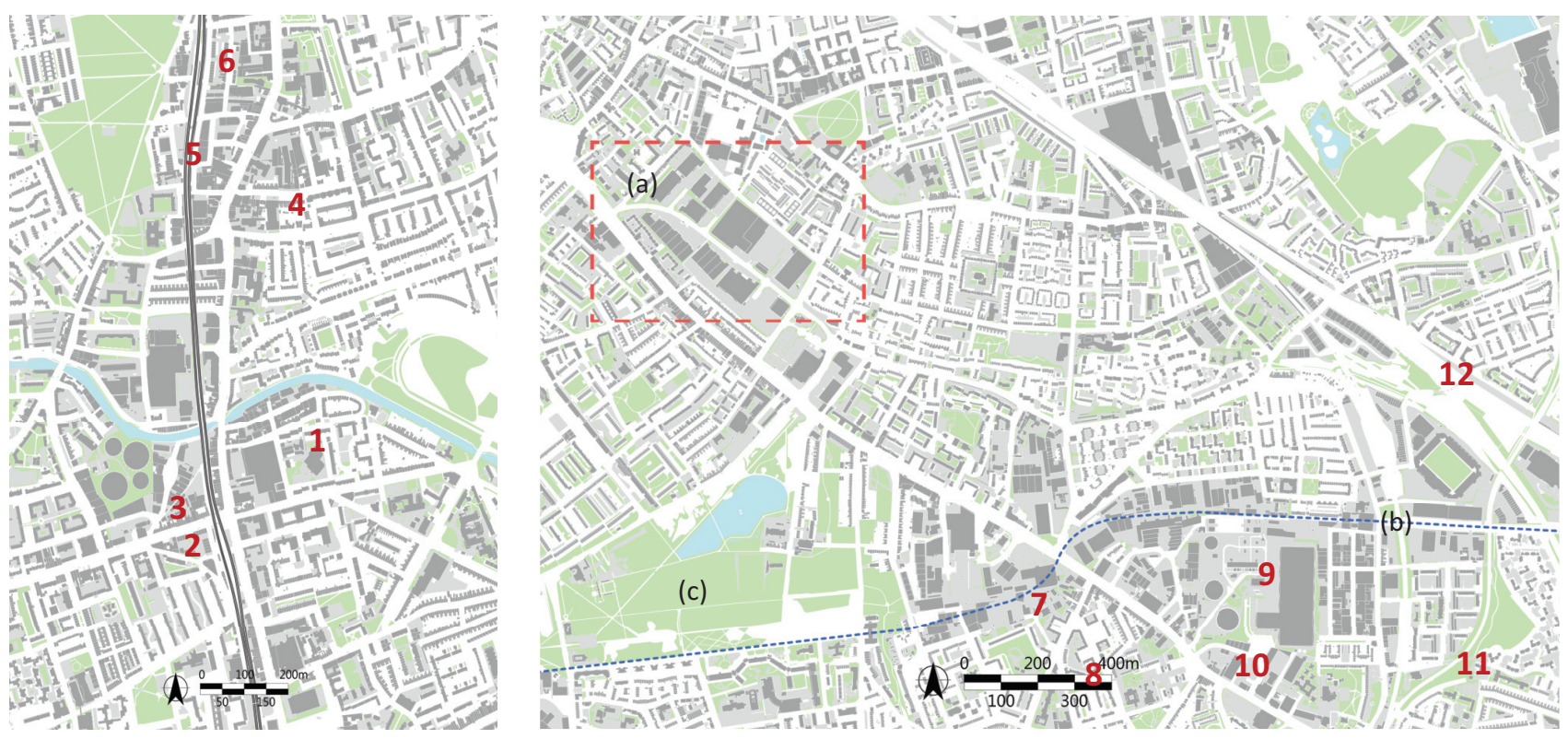

Figure 4. Present day figure-ground maps of the Hackney Mare Street (left) and the Old Kent Road (right) case studies. On the Old Kent Road map is noted (a) the site of the Bricklayers Arms Station and Goods Depot; (b) the path of the now covered Grand Surrey Canal; and (c) Burgess Park. Base map source: Ordnance Survey (2019). Created 11 December 2020.

their accessibility and relationship to the street and their immediate urban environment.

Table 1 reveals how small-scale industrial buildings and railway arches are usually dedicated to one specific activity or business primarily due to their small size, but also how the versatile internal configuration of these buildings allows for a very wide range of activities. Depending on the immediate urban environment, these types open either directly onto the street, a private alley, or a front yard which is connected to the main road network resulting in a high degree of constitutedness (see Hanson, 2000). The clustering of small businesses along industrial streets and railway arches was historically very beneficial for businesses as it allowed for the creation of a vibrant local community of manufacturers. Unlike railway viaducts, which by their spatially restricted nature have escaped pressure for residential redevelopment, industrial streets with small-scale industrial buildings (such as Vyner Street in the Hackney case and Hatcham Mews in the Old Kent Road area) have been
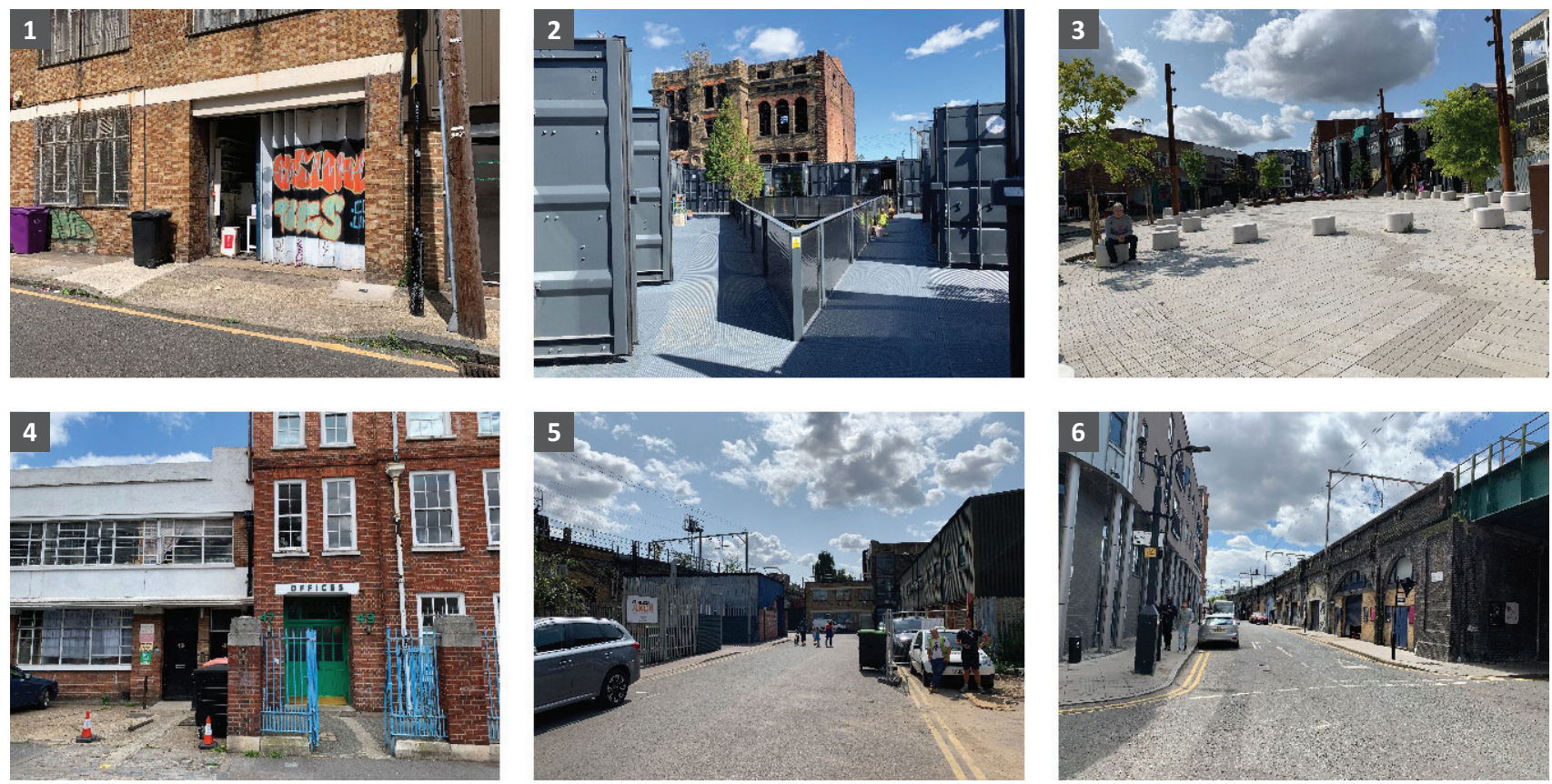

Figure 5. Present-day photographs of Hackney Mare Street. Source: Photographs taken by the authors during weekday site visits in working hours on 21 June 2019, 20 August 2019, and 5 September 2019. 

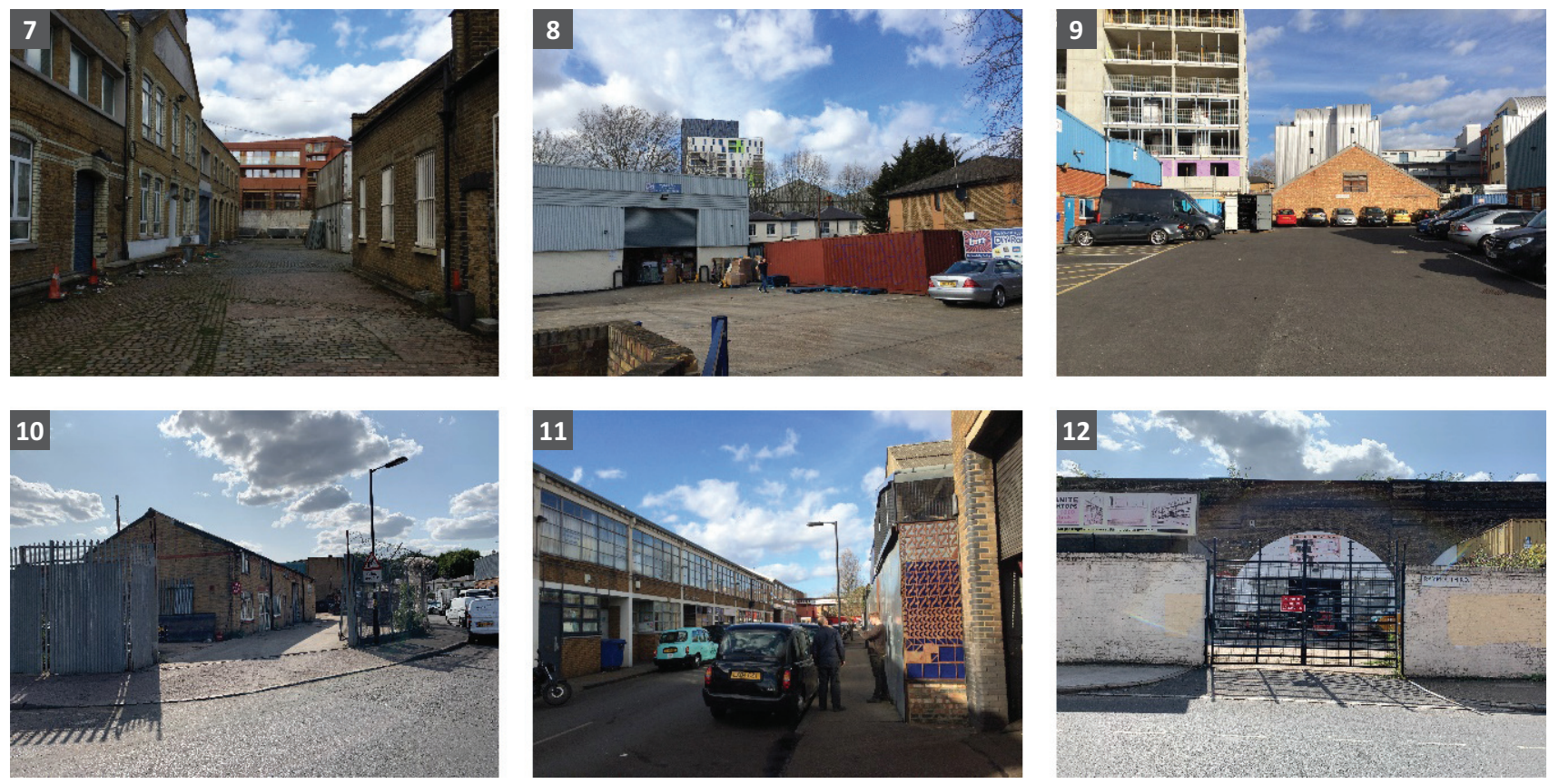

Figure 6. Present-day photographs of Old Kent Road. Source: Photographs taken by the authors during weekday site visits in working hours on 12 July 2019, 20 August 2019, and 9 October 2019.

Table 1. Summary of activities, main characteristics, and accessibility of each type of manufacturing building as found in Hackney Mare Street and Old Kent Road.

\begin{tabular}{|c|c|c|c|c|}
\hline & Type & Main activities & $\begin{array}{l}\text { Characteristics } \\
\text { and flexibility }\end{array}$ & $\begin{array}{l}\text { Access and relation to } \\
\text { the street }\end{array}$ \\
\hline & $\begin{array}{l}\text { Small scale } \\
\text { industrial } \\
\text { building }\end{array}$ & $\begin{array}{l}\text { Small-scale makers (e.g., } \\
\text { umbrellas), printers, } \\
\text { fashion and interior } \\
\text { design studios, video } \\
\text { production and car } \\
\text { repairs. }\end{array}$ & $\begin{array}{l}\text { Smaller units usually } \\
\text { fitted to one specific } \\
\text { activity or business. } \\
\text { Flexible type that can be } \\
\text { fitted to a wide range of } \\
\text { manufacturing and light } \\
\text { industrial activities. }\end{array}$ & $\begin{array}{l}\text { Direct access from the } \\
\text { street through a larger } \\
\text { entrance. Direct relation } \\
\text { to the street forming an } \\
\text { informal type of } \\
\text { environment. }\end{array}$ \\
\hline & $\begin{array}{l}\text { Railway } \\
\text { arches }\end{array}$ & $\begin{array}{l}\text { Vehicle repairs, garages, } \\
\text { food manufacturing, } \\
\text { building related } \\
\text { manufacturing, interior } \\
\text { design, architecture } \\
\text { offices, retail, } \\
\text { warehouses, breweries, } \\
\text { and other commercial } \\
\text { activities. }\end{array}$ & $\begin{array}{l}\text { Standardised open-floor } \\
\text { internal space with } \\
\text { potential to connect } \\
\text { more than one arch. Very } \\
\text { flexible type as railway } \\
\text { arches can easily } \\
\text { accommodate new and } \\
\text { diverse uses due to their } \\
\text { standardised } \\
\text { dimensions. }\end{array}$ & $\begin{array}{l}\text { Access via one large } \\
\text { main entrance usually a } \\
\text { large door or a roller } \\
\text { shutter door. Direct } \\
\text { relation to the street } \\
\text { forming an informal type } \\
\text { of environment. }\end{array}$ \\
\hline & $\begin{array}{l}\text { Industrial } \\
\text { estates }\end{array}$ & $\begin{array}{l}\text { Small-scale } \\
\text { manufacturers, larger } \\
\text { building related } \\
\text { manufacturers, food } \\
\text { processing, and various } \\
\text { non-manufacturing } \\
\text { related activities such as } \\
\text { artists, designers, and } \\
\text { other services. }\end{array}$ & $\begin{array}{l}\text { Group of buildings that } \\
\text { include distinct } \\
\text { businesses organised } \\
\text { around a central shared } \\
\text { open space (i.e., a yard } \\
\text { or court). Flexible type } \\
\text { that can house a wide } \\
\text { range of activities. }\end{array}$ & $\begin{array}{l}\text { Access to the estate } \\
\text { through one main gate } \\
\text { and then each individual } \\
\text { building is accessed via } \\
\text { the shared internal } \\
\text { courtyard. Distant } \\
\text { relation to the street } \\
\text { forming a rule-based } \\
\text { environment. }\end{array}$ \\
\hline
\end{tabular}


Table 1. Summary of activities, main characteristics, and accessibility of each type of manufacturing building as found in Hackney Mare Street and Old Kent Road.

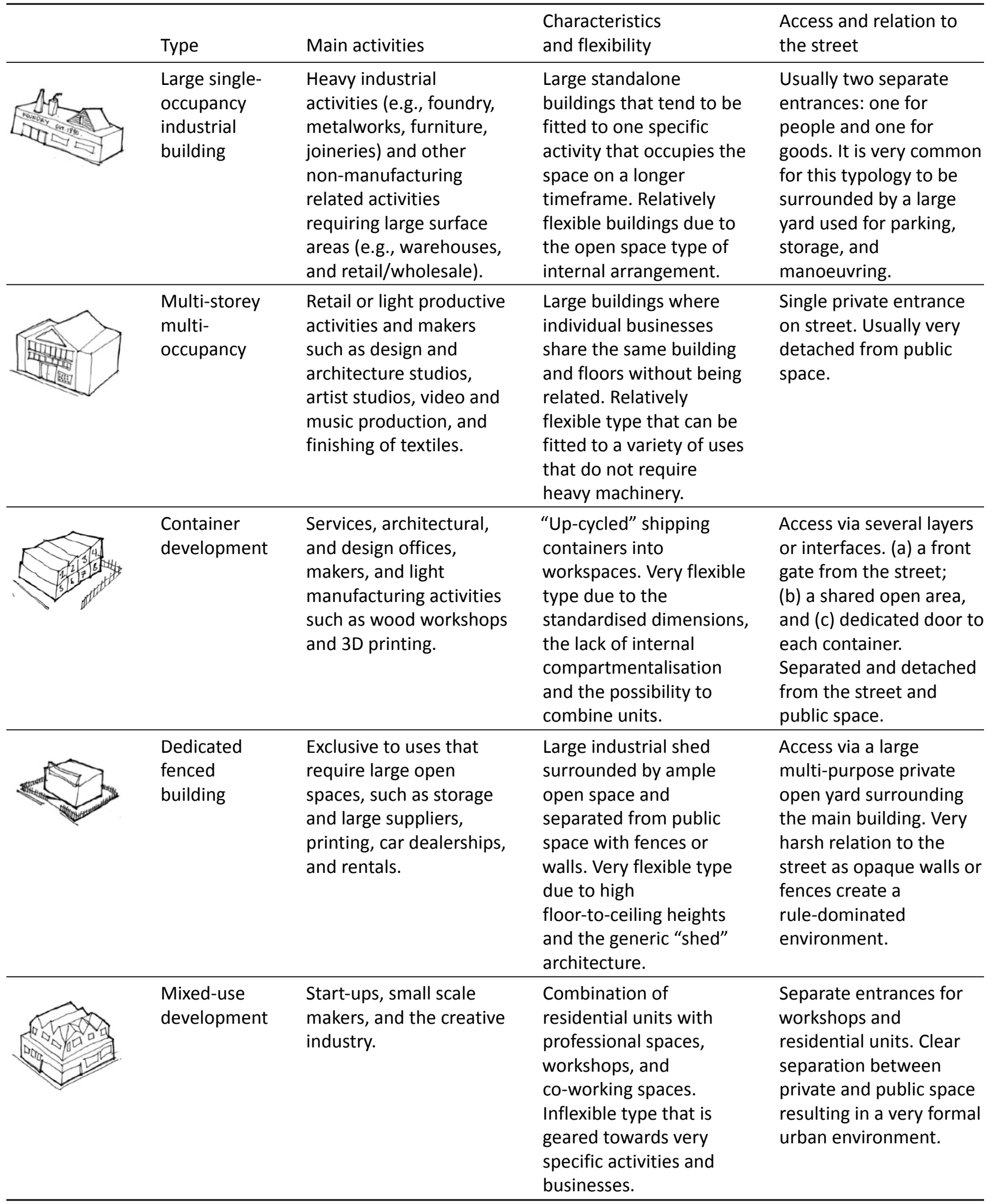

subject to piecemeal residential and commercial gentrification. Mixed-use industrial/residential buildings, as a new typology, are often integrated into these environments. According to a business owner in Vyner Street, the transformation of the urban landscape from an indus- trial to an increasingly residential one has eroded the thriving community of workers.

Single-occupancy large industrial buildings are uncommon, given the dominance of smaller manufacturers in these inner London urban environments. Older 

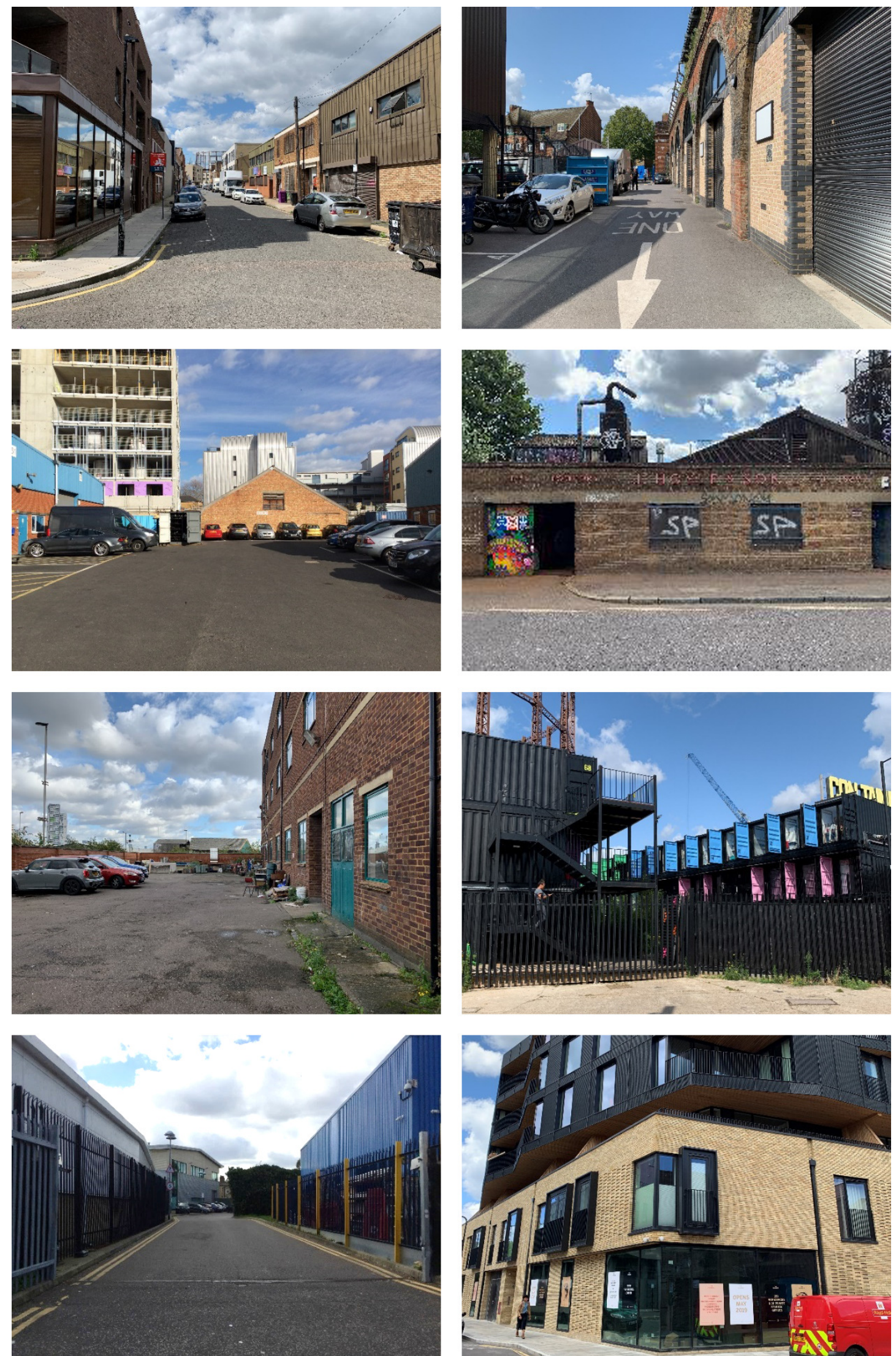

Figure 7. Photographs of manufacturing building typologies. From top to bottom and left to right: small-scale industrial buildings, railway arches, industrial estates, large single-occupancy industrial, multi-storey multi-occupancy, containers, dedicated fenced building, and mixed-use developments. Source: Photographs taken by the authors during weekday site visits in working hours on 21 June 2019, 12 July 2019, 20 August 2019, 5 September 2019, and 9 October 2019. 
buildings, such as the Foundry in Hackney, have a strong relationship to the street, whereas newer large-scale industrial buildings tend to accommodate more vehicular movements and car parking within, and therefore their relationship to the street is more similar to that of industrial estates. These buildings tend to accommodate one specific activity that occupies the space over a longer timeframe and, due to their massive size, they are rarely found in dense urban areas with smaller plot sizes. Industrial estates-more dominant in the Old Kent Road area but found in both cases-are purposedly built with a high floor-to-ceiling ratio and are optimal for heavy industrial activities and other non-manufacturing related activities that require a substantial surface area to operate. Transforming and fitting these buildings to new activities is usually easy given their open space design. However, their industrial character has served to protect these areas from piecemeal redevelopment and gentrification. Industrial estates are usually accessed through one main entrance and normally comprise a large multifunctional yard used for parking, storage, loading, unloading, and manoeuvring. This results in a very low degree of constitutedness as the very large size of these buildings and the relatively few entrances create large impenetrable spaces with a distant relationship to the street, and physical barriers that clearly separate pub- lic and private spaces. Although there may be businessto-business relationships established within these industrial estates, their spatial separation from the street and broader environment precludes their contribution to a sense of local community.

Container developments (only found in the Hackney Mare Street case) are small-scale and designed to accommodate start-ups and new businesses requiring small, flexible space. Containers are, by their nature, cheap and flexible-it is common for companies to expand and use more than one container. The businesses occupying space in container developments tend to be car-free and there is no direct vehicular access to the units, with a single entrance to the development from the street normally served by smaller, narrower streets with low traffic. These spatial attributes allow for a rather informal use of space by pedestrians to the extent where, occasionally, public space is also used as an extension of the working area. Although businesses report that they value the sense of community fostered in container developments, they are isolated bubbles in the urban fabric without a direct relation to the street, resulting in an introverted typology where both work and socialising happens within it.

To better understand how each type is embedded in the urban fabric, Table 2 compares the count of each

Table 2. Count of manufacturing building typologies found in the Hackney Mare Street and Old Kent Road case studies.

\begin{tabular}{|c|c|c|c|c|c|c|c|}
\hline Key & Type & Scale & $\begin{array}{l}\text { Street / estate } \\
\text { based } \\
\text { typology }\end{array}$ & $\begin{array}{c}\text { Unit } \\
\text { count } \\
\text { (Hackney) }\end{array}$ & $\begin{array}{c}\text { Typologies as a \% } \\
\text { of total industrial } \\
\text { units surveyed } \\
\text { (Hackney) }\end{array}$ & $\begin{array}{l}\text { Unit } \\
\text { count } \\
\text { (OKR) }\end{array}$ & $\begin{array}{c}\text { Typologies as a \% } \\
\text { of total industrial } \\
\text { units surveyed } \\
\text { (OKR) }\end{array}$ \\
\hline 1 & $\begin{array}{l}\text { Small scale } \\
\text { industrial } \\
\text { building }\end{array}$ & Small scale & Street & 35 & $13 \%$ & 59 & $17 \%$ \\
\hline 3 & $\begin{array}{l}\text { Railway } \\
\text { arches }\end{array}$ & Small scale & Street & 71 & $26 \%$ & 69 & $20 \%$ \\
\hline 6 & $\begin{array}{l}\text { Industrial } \\
\text { estates }\end{array}$ & Large scale & Estate & 2 & $1 \%$ & 148 & $42 \%$ \\
\hline 10 & $\begin{array}{l}\text { Large single- } \\
\text { occupancy } \\
\text { industrial }\end{array}$ & Large scale & Street & 13 & $5 \%$ & 33 & $9 \%$ \\
\hline 17 & $\begin{array}{l}\text { Multi-storey } \\
\text { multi-occupancy }\end{array}$ & Large scale & Street & 9 & $3 \%$ & 10 & $3 \%$ \\
\hline 4 & Containers* & $\begin{array}{l}\text { Small scale } \\
\text { activity / large } \\
\text { scale }\end{array}$ & Estate & 132 & $48 \%$ & 0 & $0 \%$ \\
\hline 5 & $\begin{array}{l}\text { Dedicated fenced } \\
\text { building }\end{array}$ & Large scale & Estate & 0 & $0 \%$ & 31 & $9 \%$ \\
\hline \multirow[t]{2}{*}{14} & $\begin{array}{l}\text { Mixed use } \\
\text { development }\end{array}$ & Large scale & Street & 11 & $4 \%$ & 1 & $0 \%$ \\
\hline & TOTAL & & & 273 & $100 \%$ & 351 & $100 \%$ \\
\hline
\end{tabular}

\footnotetext{
*Containerville: 78 containers. *Gossamer city: 54 current residents.
} 
building type in Hackney Mare Street and the Old Kent Road which are then mapped in Figure 8. Both table and figure confirm a clear dominance of small-scale units in Hackney Mare Street and a predominance of larger building types in the Old Kent Road area.
Larger typologies such as industrial estates, large single-occupancy industrial, multi-storey multioccupancy, and dedicated fenced buildings are dominant in the Old Kent Road (69\%) but very limited in Hackney (9\%). These observations confirm the earlier

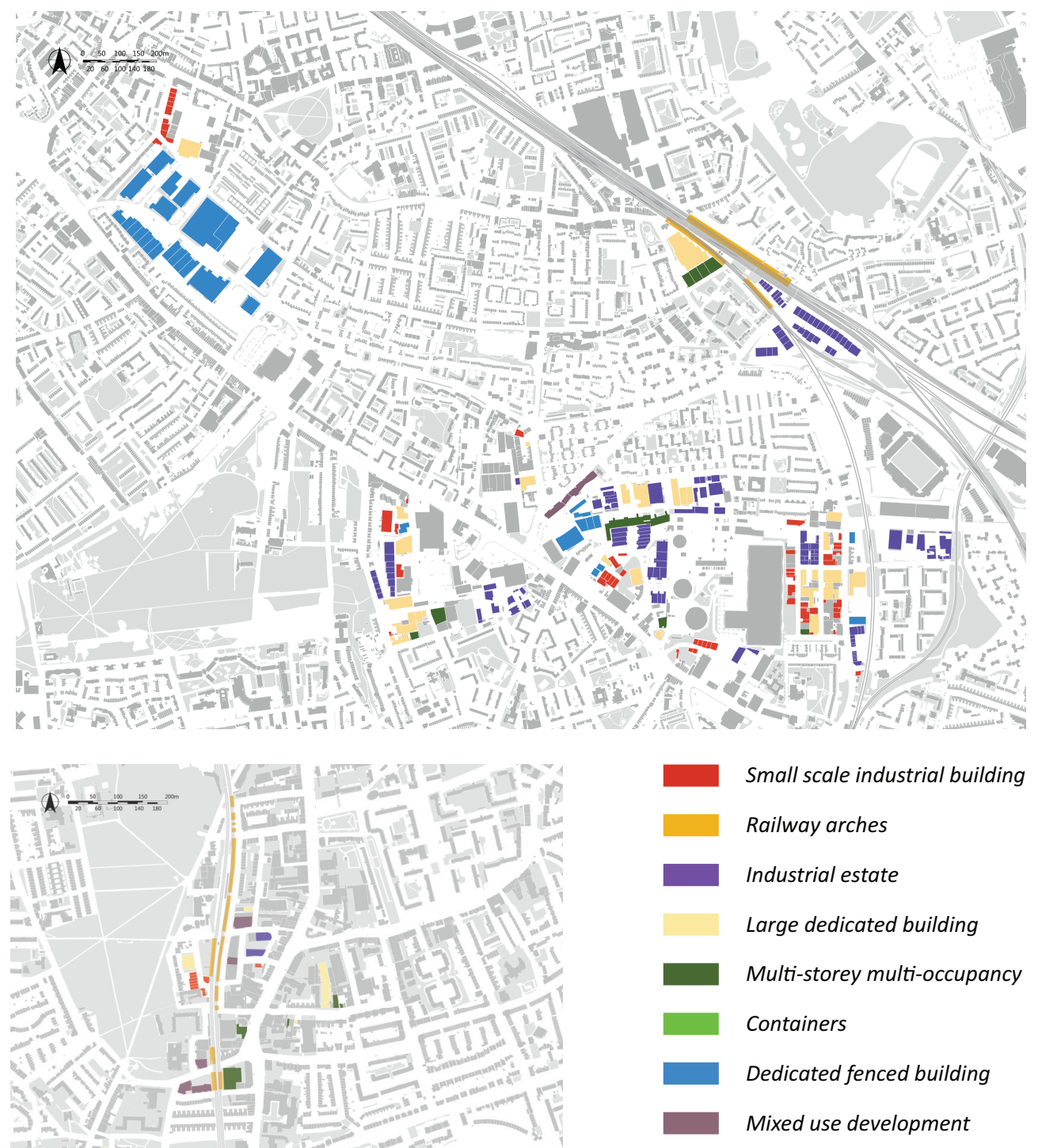

Figure 8. Maps of the Old Kent Road (top) and Hackney Mare Street (bottom) highlighting the geographical distribution of industrial building types, based on site observations. Base map source: Ordnance Survey (2019). Created 11 December 2020. 
analysis which revealed the tighter urban morphology of Hackney Mare Street, made of smaller plots, in contrast to a looser one in the Old Kent Road, composed of larger parcels.

The data also shows that small-scale industrial buildings and railway arches comprise relatively equal proportions of the building stock in both cases (averages of 15\% and $23 \%$ respectively). This is important since small-scale industrial buildings and railway arch typologies were the dominant industrial typologies during the earlier stages of 19th-century industrialisation. The fact that they are enduring to this day indicates that they have been able to sustain the passage of time and adapt to the changes and the needs of manufacturing for decades. Flexibility has been attributed to the modular and standardised architectural features of such industrial premises (see Froy \& Davis, 2017; specifically for railway arches see Rosa, 2014) and is one key aspect underpinning their long-term sustainability. As Froy and Davis (2017) highlight, the flexible spatial configuration of railway arches facilitates business expansion and contraction with relative ease, which is paramount for businesses to be successful and remain relevant.

The clustering and mix of industrial activities have also been documented as fundamental for production, exchange, and reproduction (Dovey \& Wood, 2014). Wood and Dovey $(2015$, p. 65) found that the spatial morphologies of creative clusters are not homogeneous but rather comprise a "mix of mixes" of functions and spatial interfaces. This is observed in both Hackney Mare Street and Old Kent Road as industrial building types are surrounded by residential neighbourhoods and often work to fill in the in-between spaces between infrastructure and the rest of the urban fabric generating an uncommonly mixed-use urban landscape. Nevertheless, within this very diverse urban environment and a mix of typologies, a clear clustering of types can be observed. The two maps in Figure 8 highlight how in both cases industrial activity and manufacturing is still clustering around longstanding infrastructure, such as railways and waterbodies, and that within these clusters smaller groupings of building types are found.

In the Old Kent Road area, industrial estates, large single-occupancy buildings, dedicated fenced buildings, and small-industrial buildings tend to be clustered closer to their relative type. The same is apparent in Hackney Mare Street where small-scale industrial buildings remain closely grouped along the Regent's Canal. It is also noteworthy that the only two container developments are located around the same public space. It is unclear whether this is deliberate, but their focus on building strong communities could be a fundamental factor in their location rationale. As for the dedicated fenced building typology, it is for the most part isolated from other industrial buildings as this typology requires a very large amount of open space. It is therefore not surprising that, in the Old Kent Road, this type is almost exclusively found on the former site of the Bricklayers Arms Station and Depot, while it is non-existent in Hackney Mare Street. It is noticeable that in Hackney Mare Street a more localised approach to manufacturing and productive activities has been embraced by promoting smaller units and developments such as container villages which are more appropriate for start-ups and small-scale makers. These retain many of Hanson's (2000) pre-modern morphological attributes of a street-based environment where space is continuous and composed of open and outward-facing building typologies, attributes which have proved to be a source of resilience. In contrast, in the Old Kent Road area, industry and manufacturing are predominantly accommodated in larger inward-facing industrial estates and tend to be characterised by heavier manufacturing and industrial activities.

However, that is not to say that Hackney Mare Street has remained in a "pre-modern" stage. Instead, there is a higher proportion of start-ups and small companies around Hackney Mare Street, which are in transitionary states and are likely to eventually outgrow their first location and relocate, hence, their fit in smaller-scale building typologies. In contrast, although start-ups and small firms are found in the Old Kent Road area, more traditional and longer-established manufacturing activities have been located there, facilitated by larger format industrial buildings with significant yard space to accommodate vehicular servicing, heavy machinery, and tools required for their operation (although the pressure for redevelopment and rapid change in the area at the time of writing means these observations are time sensitive). Therefore, the lack of "newer" building types, such as container developments and mixed-use buildings, in the Old Kent Road area suggests that there is less demand from new manufacturing businesses and start-ups.

The built environments in Hackney Mare Street and the Old Kent Road have evolved differently over time and have resulted in two very different outcomes with certain typologies dominating more in one area than the other. The massive events of urban transformation that altered the Old Kent Road allowed the resulting massive plots to house large buildings whereas the mostly unchanged fabric of Hackney Mare Street allowed it to retain its dense urban character. The smaller plots found around Hackney Mare Street have allowed the urban environment to change and evolve gradually, facilitating gentrification but avoiding large scale redevelopment, whereas the Old Kent Road's looser form and larger individual plots and buildings have led to the opposite: an urban fabric struggling to survive in the face of development pressure without extensive (re)development. This illustrates the urban tissue's varying degrees of flexibility and adaptability to change but also the complexity underpinning spaces of urban manufacturing-which was also highlighted by Lane and Rappaport (2020) in American cities. From an analysis of the changing spatial morphologies of both areas, in the context of their historical development, we hypothesise that the pressures 
both areas are currently facing from (re)development are inexorably linked to their current urban form and the way it evolved during the 20th century. We argue that it is therefore key to look beyond the individual building types and consider the urban environments they create cumulatively. Understanding the relation between industrial typologies and their urban-morphological embedding is key to grasping the evolution of urban manufacturing and the urban context of the living city in which it is still found.

\section{Conclusions}

Much has been written about the role of residential buildings and typologies in shaping the city fabric, and this focus on housing is reinforced by planning policy in London, which places an arguably disproportionate emphasis on housing as the dominant land use in the city, with growth targets that eclipse all other land uses and activities. This article brings our attention to industrial building typologies and industrial morphologies as part of the city fabric. It has drawn parallels with the transformation of residential morphologies under architectural modernism and the associated tradition of post-war town planning, which Hanson (2000) conceptualised. In the same way that the demolition of post-war housing estates has been justified on the grounds of poor urban design and integration with the wider city fabric, so areas with a dominance of inward-looking industrial estates-whose segregation from residential areas was once justified on environmental and pollution grounds-have become targets for large scale regeneration and re-imagination.

The two inner London case study areas chosen for this research are experiencing different pressures for redevelopment, which we have argued is directly related to the evolution of the two urban environments since the late 19th century. Whereas the area around Hackney Mare Street has been subject to gentrification and piecemeal redevelopment over time, its urban form is tighter and denser and has remained largely intact, increasingly accommodating businesses in the so-called "new economy." In contrast, the Old Kent Road has been identified as a site for major redevelopment and transformation through a targeted policy-led approach, which has already prompted significant residential-led development activity in the area threatening up to 1,000 businesses (vitalokr.com). This, we have suggested, is closely linked to its relative dominance by larger post-war industrial estates, that emerged in the tradition of architectural modernism and "rational" post-war town planning, and which renders its industrial activity - that has included larger, more traditional manufacturers as well as smaller, new ones-relatively invisible.

As this article shows, inner London districts with concentrations of manufacturing comprise a wide variety and diversity of industrial building typologies, all accommodating different types of activities and sizes of businesses. These include older "traditional" manufacturers and newer "high-tech" firms, which interact in different ways with their immediate urban environments. Some require the formal access and servicing arrangements inherent in industrial estates, others benefit from the less rule-governed nature of "industrial streets," or the networking and business-to-business interaction facilitated by multi-occupancy buildings or containers. The wide variety of industrial typologies and urban environments required to sustain an industrial ecology and support the growth of urban manufacturing in the city is-we suggest-underexplored and inadequately understood. This article is a contribution towards a new framework of industrial typologies for policy purposes. Together with recent work on the design of urban manufacturing (Lane \& Rappaport, 2020) and the re-integration of material production into the life of the working city (Davis, 2019), we believe this points to an important emerging research agenda. It is one which fundamentally brings our attention to the importance of place in both determining the location decisions of manufacturers-hitherto less explored in the literature-and their fate once established in their urban environments.

\section{Acknowledgments}

This research was funded by the UCL Bartlett Synergy Grant, which promotes cross-disciplinary research through the various departments of the Bartlett Faculty of the Built Environment. The authors would like to thank the businesses in our two case study contexts who gave their time to be interviewed for the project. We gratefully acknowledge the work of Nicolas Palominos Ortega and Francesca Froy in the earlier stages of this research project, providing important context for this work to emerge, as well as their insights into businesses in the Hackney Mare Street area, following their earlier research there as part of the Cities of Making project. In addition, we thank Nicolas for his work on the Londonlevel graphics. Finally, we are also grateful to Mark Brearley, proprietor of Kaymet Ltd., for giving his time to brief us on important emerging policy contexts and challenges for businesses in the Old Kent Road area.

\section{Conflict of Interests}

The authors declare no conflict of interests.

\section{References}

British History Online. (n.d.). Home. https://www.britishhistory.ac.uk

Cargill Thompson, J. (2018). "This is not nothing:" Everyday places and identities on London's Old Kent Road (Unpublished master's thesis). University College London, London, UK.

Chapple, K. (2014). The highest and best use? Urban 
industrial land and job creation. Economic Development Quarterly, 28(4), 300-313. https://doi.org/ $10.1177 / 0891242413517134$

Cox, K. R., \& Mair, A. (1988). Locality and community in the politics of local economic development. Annals of the Association of American Geographers, 78(2), 307-325.

Curran, W. (2007). "From the frying pan to the oven:" Gentrification and the experience of industrial displacement in Williamsburg, Brooklyn. Urban Studies, 44(8), 1427-1440.

Curran, W. (2010). In defence of old industrial spaces: Manufacturing, creativity and innovation in Williamsburg, Brooklyn. International Journal of Urban and Regional Research, 34(4), 871-885.

Davis, H. (2019). Working cities: Architecture, place and production. Routledge.

Davis, J., \& Renski, H. (2020). Do industrial preservation policies protect and promote urban industrial activity? Journal of the American Planning Association, 86(4), 431-442. https://doi.org/10.1080/01944363. 2020.1753563

Dempwolf, C. (2010). An evaluation of recent industrial land use studies: Do theory and history make better practice? Unpublished manuscript. http:// www.academia.edu/319809/An_Evaluation_of_ Recent_Industrial_Land_Use_Studies_Do_Theory_ and_History_Matter_In_Practice

De Propris, L., \& Bailey, D. (2020). Industry 4.0 and regional transformations. Routledge. https://doi. org/10.4324/9780429057984

Domenech, T., Froy, F., \& Palominos, N. (2020). Case study report: The Maker Mile in East London. Cities of Making. https://citiesofmaking.com/case-studyreport-the-maker-mile-in-east-london

Dovey, K., \& Wood, S. (2014). Public/private urban interfaces: Type, adaptation, assemblage. Journal of Urbanism: International Research on Placemaking and Urban Sustainability, 8(1), 1-16. https://doi.org/ $10.1080 / 17549175.2014 .891151$

Duman, A. (2012). Dispatches from "the frontline of gentrification." City, 16(6), 672-685. https://doi.org/ 10.1080/13604813.2012.737507

Ferm, J. (2016). Preventing the displacement of small businesses through commercial gentrification: Are affordable workspace policies the solution? Planning Practice \& Research, 31(4), 402-419. https://doi.org/ 10.1080/02697459.2016.1198546

Ferm, J. (2021). Governing urban development on industrial land in global cities: Lessons from London. In S. Bunce, N. Livingstone, L. March, S. Moore, \& A. Walks (Eds.), Critical dialogues of urban governance, development, and activism: London and Toronto (pp. 115-129). UCL Press.

Ferm, J., \& Jones, E. (2015). London's industrial land: Cause for concern? University College London.

Ferm, J., \& Jones, E. (2017). Beyond the post-industrial city: Valuing and planning for industry in London.
Urban Studies, 54(14), 3380-3398. https://doi.org/ $10.1177 / 0042098016668778$

Froy, F., \& Davis, H. (2017). Pragmatic urbanism: London's railway arches and small-scale enterprise. European Planning Studies, 25(11), 2076-2096.

Greater London Authority. (2016). London Industrial land supply and economy study 2015. We Made That. http://www.wemadethat.co.uk/projects/view/ london-industrial-land-supply-economy-study

Greater London Authority. (2021a). Secretary of State's response. https://www.london.gov.uk/what-we-do/ planning/london-plan/new-london-plan/secretarystates-response

Greater London Authority. (2021b). The London Plan 2021: Spatial development strategy for Greater London. https://www.london.gov.uk/what-we-do/ planning/london-plan/new-london-plan/londonplan-2021

Griffiths, S. (2017). Manufacturing innovation as spatial culture: Sheffield's cutlery industry c.1750-1900. In I. Van Damme, B. Blondé, \& A. Miles (Eds.), Cities and creativity from the renaissance to the present (pp. 127-153). Routledge.

Grodach, C., \& Martin, D. (2020). Zoning in on urban manufacturing: Industry location and change among lowtech, high-touch industries in Melbourne, Australia. Urban Geography, 42(4), 1-23. https://doi.org/ 10.1080/02723638.2020.1723329

Grodach, C., O'Connor, J., \& Gibson, C. (2017). Manufacturing and cultural production: Towards a progressive policy agenda for the cultural economy. City, Culture and Society, 10(1), 17-25. https://doi.org/10.1016/ j.ccs.2017.04.003

Hamnett, C., \& Williams, P. (1980). Social change in London: A study of gentrification. The London Journal, 6(1), 51-66.

Hall, P. G. (1962). The industries of London since 1861. Routledge. https://doi.org/10.4324/97802037 16670

Hanson, J. (2000). Urban transformations: A history of design ideas. Urban Design International, 5(2), 97-122.

Heikkila, E., \& Hutton, T. A. (1986). Toward an evaluative framework for land use policy in industrial districts of the urban core: A qualitative analysis of the exclusionary zoning approach. Urban Studies, 23(1), 47-60.

Hills, R. M., Jr., \& Schleicher, D. (2010). The steep costs of using noncumulative zoning to preserve land for urban manufacturing. The University of Chicago Law Review, 77(249), 249-273.

Jacobs, J. (1969). The economy of cities. Random House.

Kropf, K. (2017). The handbook of urban morphology. Wiley.

Lane, R. N., \& Rappaport, N. (2020). The design of urban manufacturing. Routledge.

Leigh, N. G., \& Hoelzel, N. (2012). Smart growth's blind side: Sustainable cities need productive urban indus- 
trial land. Journal of the American Planning Association, 78(1), 87-103.

London Data Store. (2019). Directory of London businesses. http://data.london.gov.uk

Ordnance Survey. (2019). Digimap Ordnance Survey collection. https://digimap.edina.ac.uk

Palominos Ortega, N., Griffiths, S., Froy, F., \& Ferm, J. (2020, July 21-23). Visualising manufacturing activity in London [Conference paper]. Proceedings of the GISRUK 2020 Conference, London, UK. https:// discovery.ucl.ac.uk/id/eprint/10105882

Raco, M., \& Tunney, E. (2010). Visibilities and invisibilities in urban development: Small business communities and the London Olympics 2012. Urban Studies, 47(10), 2069-2091.

Rosa, B. (2014). Beneath the arches: Re-appropriating the spaces of infrastructure in Manchester [Doctoral dissertation, The University of Manchester]. The University of Manchester's Repository. https://www.research.manchester.ac.uk/portal/en/ theses/beneath-the-arches-reappropriating-thespaces-of-infrastructure-in-manchester(333f6f40- 4f4f-4689-ab2f-0019fff88ede).html

Scott, A. J. (1982). Locational patterns and dynamics of industrial activity in the modern metropolis. Urban Studies, 19(2), 111-141.

Scott, A. J. (2006). Creative cities: Conceptual issues and policy questions. Journal of Urban Affairs, 28(1), 1-17.

Soja, E. (2003). Writing the city spatially. City, 7(3), 269-280. https://doi.org/10.1080/1360481032000 157478

Southwark Council. (2021). A brief history of Old Kent Road. https://oldkentroad.org.uk/history

Space Syntax. (2020). OpenMapping. https://space syntax.com/digital/openmapping

Vaughan, L. S., Dhanani, A., \& Griffiths, S. (2013). Beyond the suburban high street cliché: A study of adaptation to change in London's street network, 1880-2013. Journal of Space Syntax, 4(2), 221-241.

Wood, S., \& Dovey, K. (2015). Creative multiplicities: Urban morphologies of creative clustering. Journal of Urban Design, 20(1), 52-74.

\section{About the Authors}
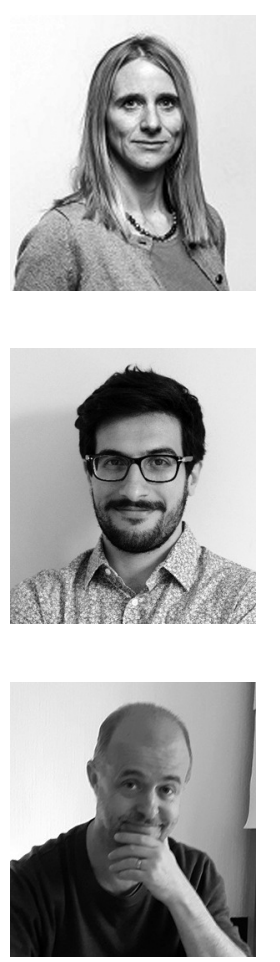

Jessica Ferm $(\mathrm{PhD})$ is associate professor in planning and urban management and director of undergraduate programmes at the Bartlett School of Planning of the University College London. She is a commissioner on the Industrial Land Commission, convened by the Centre for London, and was a member on the London Industrial Land and Logistics Steering Board, chaired by London First and the Greater London Authority. Her research centres on the governance of land use conflicts between industry and housing in cities with high land values, with an expertise on London planning.

Dimitrios Panayotopoulos-Tsiros (PhD) is a research associate and teaching assistant at the Bartlett School of Planning of the University College London, with a background in architecture and urban planning. His research is situated in the field of urban studies and focuses on the patterns of urban transformation, the perception of marginalised and liminal urban spaces, and the relevance of urban manufacturing in contemporary urban settings.

Sam Griffiths (PhD) is associate professor in spatial cultures in the Space Syntax Laboratory at the Bartlett School of Architecture of the University College London. His research focuses on the historical relationship between people and built environments, the spatial culture of manufacturing towns, and space syntax as an interdisciplinary research perspective. He is co-editor, with Alexander von Lünen, of Spatial Cultures: Towards a New Morphology of Cities (Routledge, 2016) and has recently published Writing the Materialities of the Urban Past: Cities and the Architectural Topography of Historical Imagination (Routledge, 2021). 